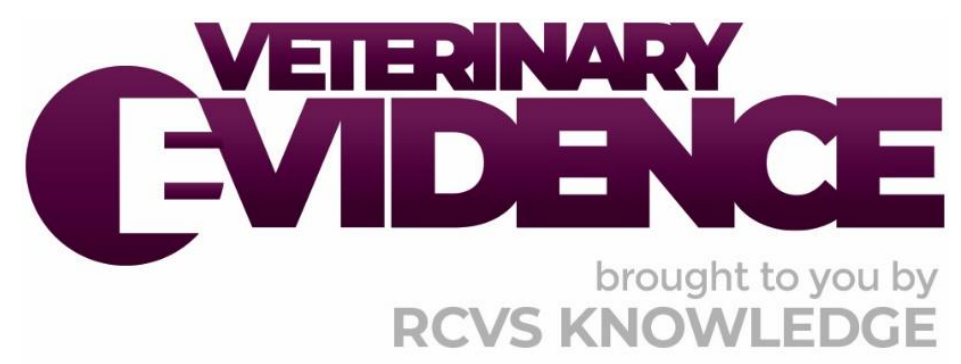

\title{
Continuous digital hypothermia in the prevention and treatment of acute equine laminitis
}

\section{A Knowledge Summary by}

Karen Pickering BVSc CertAVP (ED) PgCert VPS MRCVS ${ }^{1^{*}}$ Joanne Ireland BVMS PhD CertAVP(EM) FHEA MRCVS ${ }^{2}$

\footnotetext{
${ }^{1}$ The Donkey Sanctuary, Veterinary Department, Brookfield Farm, Honiton, EX14 9SU

${ }^{2}$ University of Liverpool, Institute of Veterinary Science, Leahurst Campus, Chester High Road, Neston, CH64 7TE

*Corresponding Author (karen.pickering66@gmail.com)
}

ISSN: 2396-9776

Published: 09 Dec 2020

in: The Veterinary Evidence journal Vol 5, Issue 4

DOI: 10.18849/VE.V5I4.307

Reviewed by: Julia Dubuc (DMV, DÉS, DACVS-LA, M.Sc, AFHEA, MRCVS) and Andrew Van Eps (BVSc, PhD, MACVSc, DACVIM)

Next Review Date: 26 Aug 2021 


\section{KNOWLEDGE SUMMARY}

\section{PICO question}

Does continuous digital hypothermia improve clinical outcome in equids with acute laminitis compared to supportive treatment alone?

\section{Clinical bottom line}

\section{Category of research question}

Treatment

\section{The number and type of study designs reviewed}

Six experimental randomised controlled trials and one multicentre retrospective case series were reviewed

\section{Strength of evidence}

\section{Moderate}

\section{Outcomes reported}

The outcomes reported were reduced severity of histopathological lamellar lesions in limbs treated with continuous digital hypothermia $(\mathrm{CDH}$; initiated prior to or soon after the onset of experimentally induced acute laminitis) compared to limbs remaining at an ambient temperature in all five experimental studies where histology was performed. A significant reduction was observed in the prevalence or severity of clinical signs of laminitis in limbs treated with $\mathrm{CDH}$ compared to limbs remaining at an ambient temperature. In a single retrospective case series, significantly reduced prevalence of clinical laminitis was reported amongst animals receiving $\mathrm{CDH}$ compared to those that did not in a referral hospital population of animals treated for colitis

\section{Conclusion}

There is moderate evidence to support that CDH when used prior to or in the early stages of clinical signs, may reduce the severity and progression of lamellar lesions in acute laminitis and no evidence demonstrating that it improves clinical outcome compared to supportive treatment alone. Further research into the clinical outcome of equids treated for acute laminitis using $\mathrm{CDH}$ is warranted

\section{How to apply this evidence in practice}

The application of evidence into practice should take into account multiple factors, not limited to: individual clinical expertise, patient's circumstances and owners' values, country, location or clinic where you work, the individual case in front of you, the availability of therapies and resources.

Knowledge Summaries are a resource to help reinforce or inform decision making. They do not override the responsibility or judgement of the practitioner to do what is best for the animal in their care. 


\section{The evidence}

Seven studies were found to provide evidence behind the use of continuous digital hypothermia (CDH) for the prevention or treatment of equine laminitis. Three of these are randomised, controlled, blinded, experimental studies with small sample sizes (Dern et al., 2018; Stokes et al., 2019; and van Eps et al., 2014). Another three studies were controlled, experimental studies but had further limitations due to not being fully blinded or randomised (van Eps et al., 2012; van Eps \& Pollitt; 2004; and van Eps \& Pollitt, 2009). Only one study included cases of laminitis induced by the euglycaemic hyperinsulinaemic clamp model (Stokes et al., 2019). The other five experimental studies used the oligofructose-induced laminitis model through alimentary carbohydrate overload, mimicking laminitis associated with sepsis.

Due to the experimental nature of these publications, they provide limited information regarding the clinical outcome of horses receiving $\mathrm{CDH}$ and supportive treatment, as opposed to supportive treatment alone. Only one study compared the outcomes of colitis cases that received prophylactic $\mathrm{CDH}$ with those that did not, in a referral hospital population (Kullmann et al., 2014). While including a larger sample size ( $n=130$ horses) compared to the reviewed experimental studies, this observational retrospective case series provides low level evidence and is the only publication providing evidence of $\mathrm{CDH}$ in a clinical setting.

\section{Summary of the evidence}

\begin{tabular}{|c|c|}
\hline I. (2019) & \\
\hline Population: & $\begin{array}{l}\text { Clinically normal Standardbred geldings (mean age } 6.4 \pm 1.8 \text { years). } \\
\text { All horses had retired from racing within the preceding } 4 \text { weeks, and } \\
\text { were reported to be sound, with no gross or radiographic } \\
\text { abnormalities of the feet. }\end{array}$ \\
\hline Sample size: & Eight horses \\
\hline Intervention details: & $\begin{array}{l}\text { - All horses were stabled for } 1 \text { week prior to study and fed } \\
\text { lucerne (alfalfa) hay } \\
\text { - All horses were confined to stocks (a crush) and received ad } \\
\text { libitum access to lucerne hay and water } \\
72 \text { hour experimental model: } \\
24 \text { hour control period initially, followed } \\
\text { immediately by laminitis induction via euglycaemic } \\
\text { hyperinsulinaemic clamp (EHC) model [intravenous } \\
\text { bolus of insulin ( } 45 \text { mIU/kg bodyweight (bwt)] } \\
\text { diluted in } 50 \text { ml of saline (0.9\% Sodium Chloride } \\
\text { (NaCl)) immediately followed by a continuous } \\
\text { intravenous infusion of insulin [6 mIU/kg } \\
\text { bwt/minute; concurrent continuous intravenous } \\
\text { infusion of } 50 \% \text { glucose, with the administration } \\
\text { rate adjusted to maintain euglycaemia (5 } \pm 1 \\
\text { mmol/L)] } \\
\text { euthanasia performed after } 48 \text { hours of EHC } \\
\text { For each horse: } \\
\text { random allocation of one forelimb per horse for CDH } \\
30 \text { minutes prior to commencing EHC using coin toss } \\
\text { CDH forelimb continuously cooled for the remainder } \\
\text { of the experiment via } 50 \% \text { ice and } 50 \% \text { water } \\
\text { mixture, to a level just distal to the carpus via } \\
\text { immersion within a rubber boot } \\
\text { other forelimb left at ambient temperature }\end{array}$ \\
\hline
\end{tabular}




\begin{tabular}{|c|c|}
\hline & 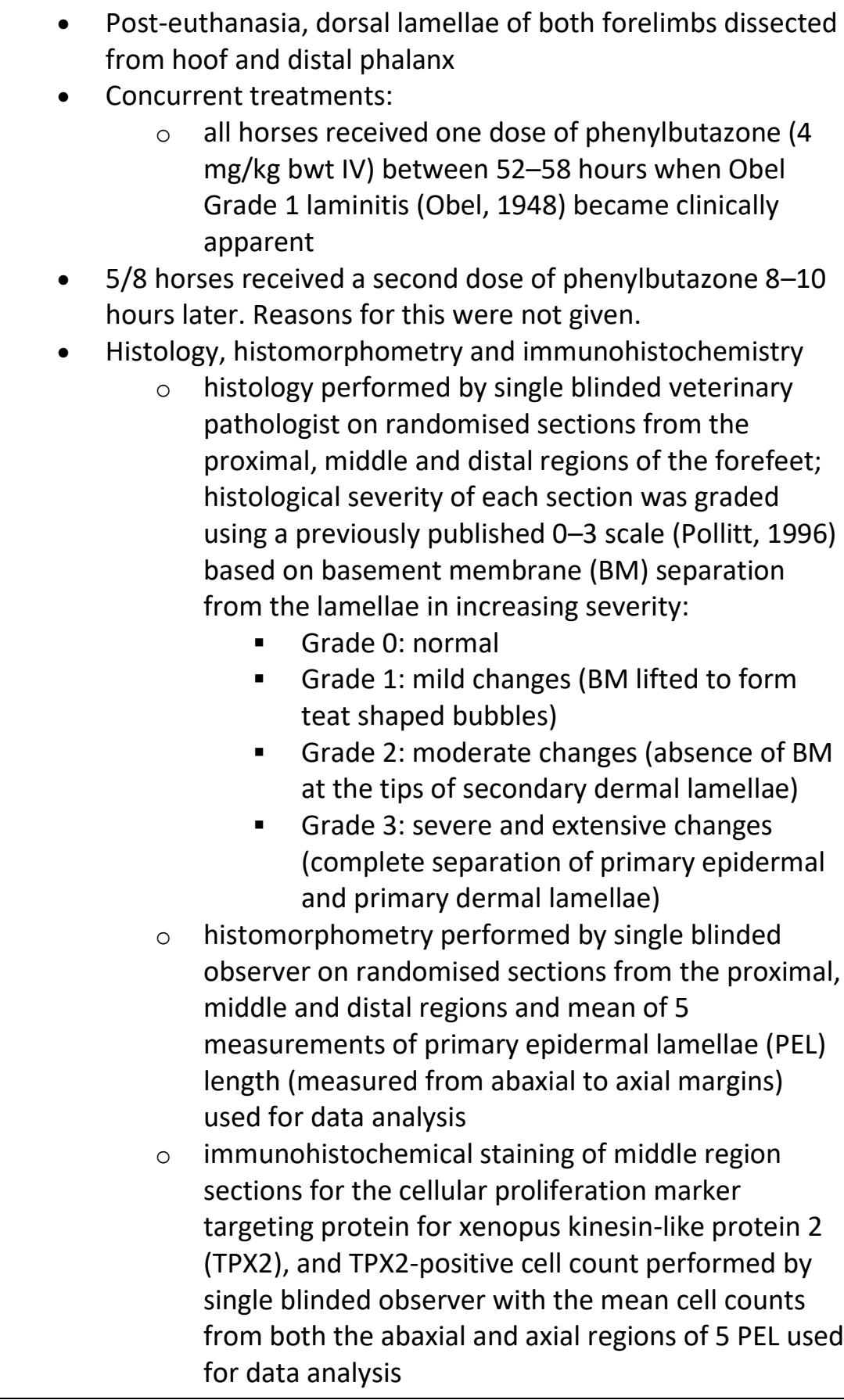 \\
\hline Study design: & Randomised, controlled (within subject), blinded, experimental \\
\hline Outcome studied: & $\begin{array}{l}\text { - Pedometer count of each forelimb independently } \\
\text { - Hoof temperature monitored using hoof wall thermistors } \\
\text { attached to data logging devices } \\
\text { - Lameness evaluation via Obel grading system (Obel, 1948) } \\
48 \text { hours post EHC initiation by videoing each horse walking } \\
\text { in a straight line for } 20 \text { metres, evaluated by a blinded } \\
\text { clinician experienced in evaluation of lameness due to } \\
\text { laminitis }\end{array}$ \\
\hline $\begin{array}{l}\text { Main findings: } \\
\text { (relevant to PICO question): }\end{array}$ & $\begin{array}{l}\text { - All eight horses developed laminitis within } 48 \text { hours of EHC } \\
\text { Pedometer counts: } \\
\text { - significant increase in ambient limb pedometer count } \\
\text { frequency during EHC ( } 24-72 \text { hours) }\end{array}$ \\
\hline
\end{tabular}




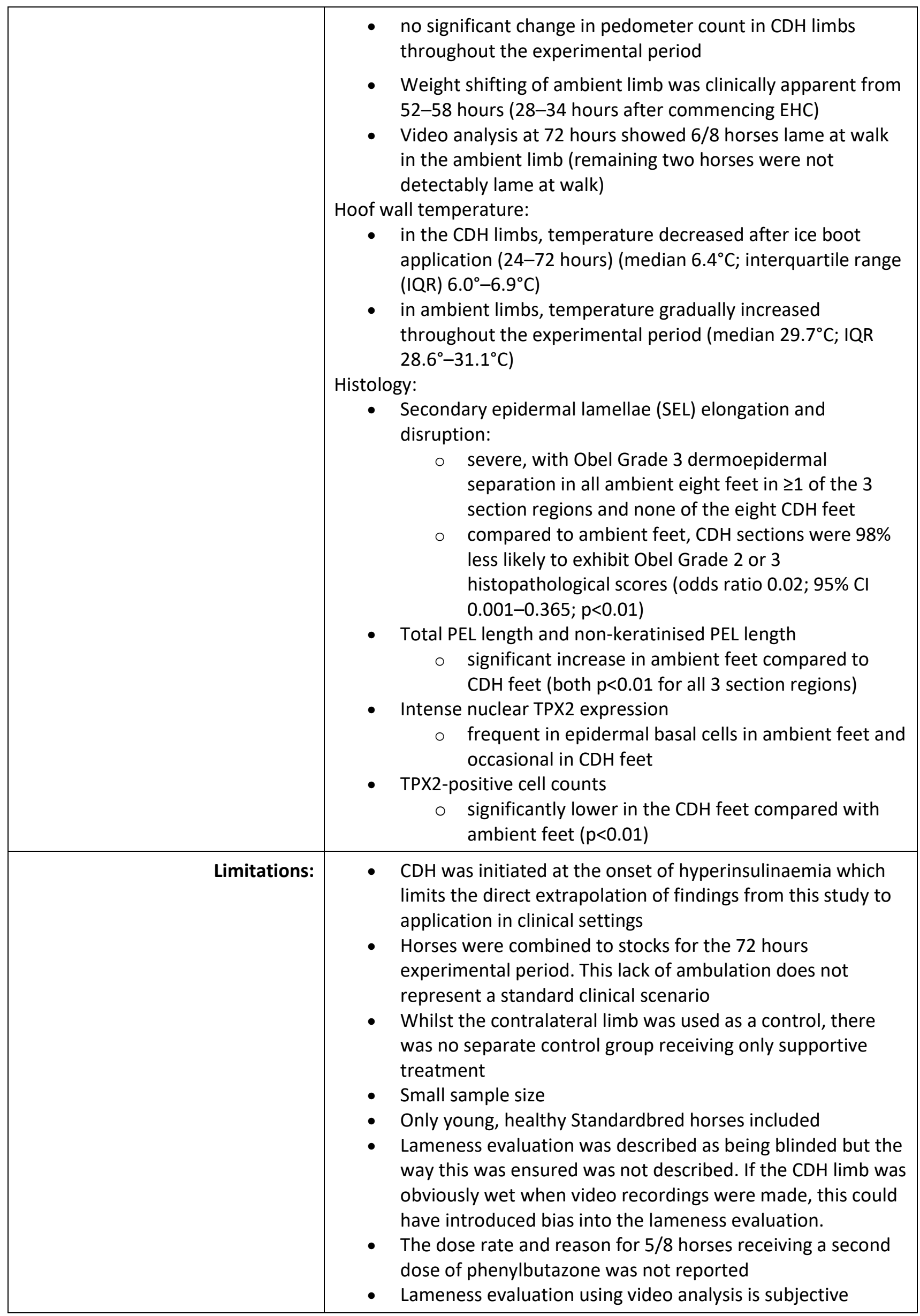




\begin{tabular}{|c|c|}
\hline Population: & $\begin{array}{l}\text { Clinically normal Standardbred geldings (aged } 3-11 \text { years). All horses } \\
\text { were reported to be sound, with no gross or radiographic } \\
\text { abnormalities of the feet. }\end{array}$ \\
\hline Sample size: & $\begin{array}{l}15 \text { horses: } n=8 \text { controls and } n=7 \text { horses administered oligofructose } \\
\text { (OF) }\end{array}$ \\
\hline Intervention details: & $\begin{array}{l}\text { - Horses randomly assigned to control or OF group } \\
\text { - All horses confined to stocks for the duration of the study } \\
\text { with constant access to hay and water } \\
\text { - In the OF group, laminitis induction achieved via bolus of } 10 \\
\text { g/kg bwt OF (up to a maximum dose of } 4.2 \mathrm{~kg} \text { ) dissolved in } \\
\text { water and administered via nasogastric tube } \\
\text { - } \mathrm{CDH} \text { was initiated } 12 \text { hours post OF administration (OF } \\
\text { group) or } 12 \text { hours after confinement in stocks (control } \\
\text { group) } \\
\text { - For each horse: } \\
\circ \quad \text { random allocation of one forelimb per horse for CDH } \\
\quad \text { CDH forelimb placed in a rubber boot filled with } 50 \% \\
\quad \text { water and } 50 \% \text { ice to the level of the proximal } \\
\quad \text { metacarpus } \\
\text { other forelimb left at ambient temperature } \\
\text { - Euthanasia via pentobarbital sodium } 36 \text { hours after the } \\
\text { beginning of the experimental period } \\
\text { The dorsal lamellae dissected from the hoof and distal } \\
\text { phalanx, snap frozen or fixed in formalin and processed } \\
\text { Assessment was via real time quantitative PCR or light } \\
\text { microscopy by blinded observers } \\
\text { Concurrent treatments: } \\
\text { all horses received a single dose of phenylbutazone } \\
\text { (4.4 mg/kg bwt IV) at onset of lameness signs (Obel } \\
\text { Grade } 1 \text { lameness (Obel, 1948)) }\end{array}$ \\
\hline Study design: & Randomised, controlled, blinded experimental study \\
\hline Outcome studied: & $\begin{array}{l}\text { - Forelimb hoof wall thermistors and pedometer devices: } \\
\circ \text { hoof wall temperature } \\
\circ \text { frequency of weight shifting } \\
\text { - Histological examination by two blinded observers, BM } \\
\text { separation from the lamellae graded using a previously } \\
\text { published 0-3 scale (Pollitt, 1996) } \\
\text { - Primary study outcomes not directly relevant to PICO } \\
\text { question (therefore not commented on further): } \\
\circ \quad \text { lamellar mRNA concentrations of inflammatory } \\
\text { mediators } \\
\circ \quad \text { lamellar leukocyte numbers }\end{array}$ \\
\hline $\begin{array}{l}\text { Main findings: } \\
\text { (relevant to PICO question): }\end{array}$ & $\begin{array}{l}\text { - All seven horses in the OF group developed laminitis (Obel } \\
\text { Grade } 1 \text { lameness (Obel, 1948)) within } 24 \text { hours of OF } \\
\text { administration } \\
\text { Hoof wall surface temperature (median and interquartile range): } \\
\text { - significant decrease in hoof wall temperature compared to } \\
\text { ambient from 12-36 hours within both OF and control }\end{array}$ \\
\hline
\end{tabular}




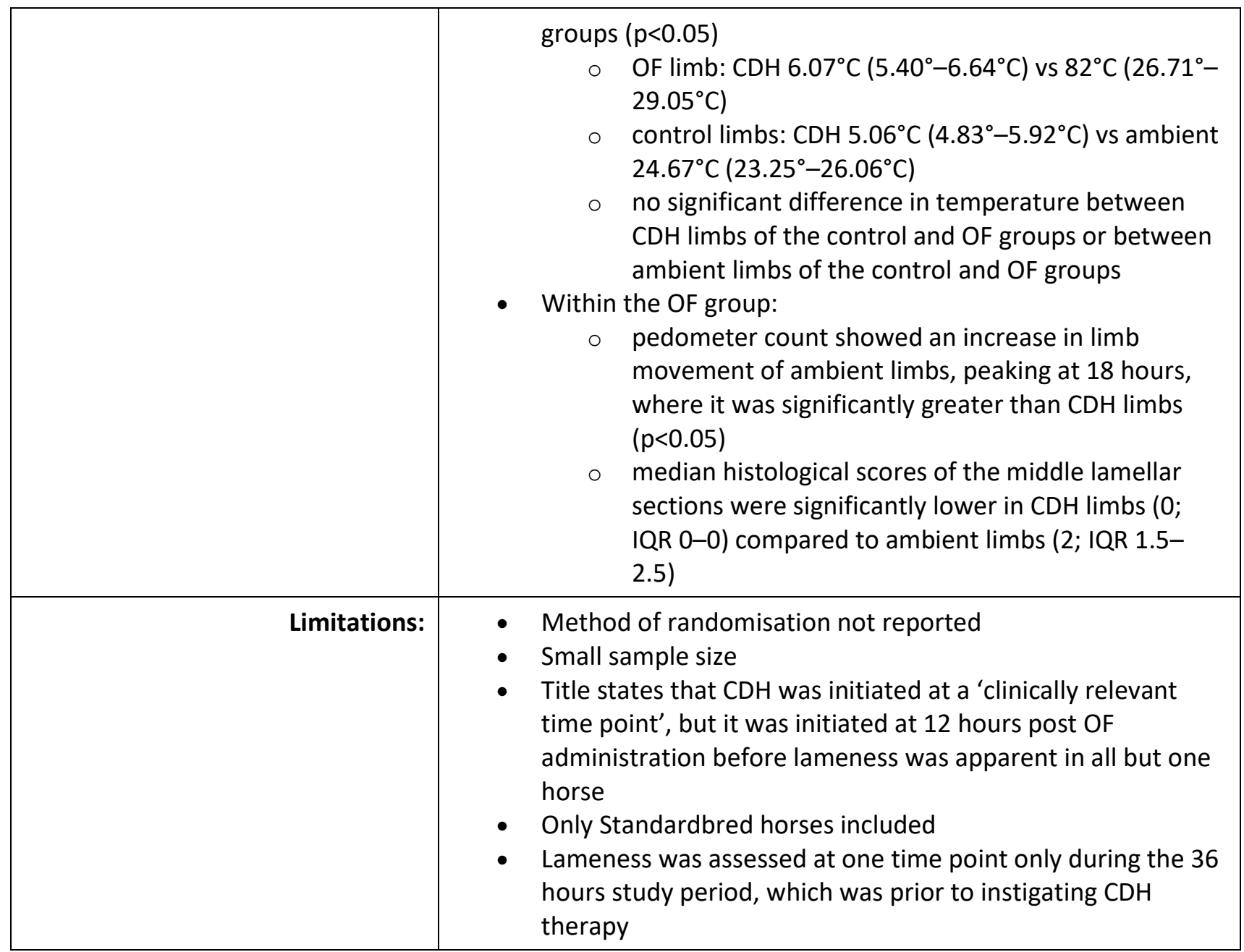

Kullmann et al. (2014)

\begin{tabular}{|c|c|}
\hline Population: & $\begin{array}{l}\text { Horses } \geq 2 \text { years old admitted to two university hospitals between } \\
\text { January } 2002 \text {-August } 2012 \text {, diagnosed with colitis, enterocolitis or } \\
\text { typhlocolitis ( } 45 \text { mares, } 78 \text { geldings, seven intact males) }\end{array}$ \\
\hline Sample size: & 130 horses: 82 from University A and 48 from University B \\
\hline Intervention details: & $\begin{array}{l}\text { - Inclusion criteria: } \\
\circ \quad \text { diagnosis of colitis, enterocolitis or typhlocolitis plus } \\
\geq 2 \text { of: fever, tachycardia, tachypnoea, leukocytosis } \\
\text { or leukopenia } \\
\circ \text { horses included whether or not they received CDH } \\
\circ \text { the horses not receiving CDH formed a control group } \\
-\quad \text { Exclusion criteria: } \\
\circ \quad \text { Horses receiving intermittent digital hypothermia } \\
\text { (feet placed intermittently (every } 2-6 \text { hours) in ice } \\
\text { or ice applied as bags or rectal sleeves wrapped } \\
\text { around the hooves) } \\
\circ \quad \text { horses admitted to hospital with acute or chronic } \\
\text { laminitis or if diagnosis of laminitis at time of } \\
\text { hospital admission } \\
\circ \quad \text { horses }<2 \text { years old as considered to have decreased } \\
\text { risk of acute laminitis }\end{array}$ \\
\hline
\end{tabular}




\begin{tabular}{|c|c|}
\hline & $\begin{array}{l}\text { draught, pony or miniature breed or equine } \\
\text { metabolic syndrome diagnosed due to increased risk } \\
\text { of acute laminitis }\end{array}$ \\
\hline Study design: & Multicentre retrospective case series \\
\hline Outcome studied: & $\begin{array}{l}\text { - Development of laminitis } \\
\circ \quad \text { diagnosis of laminitis based on Obel lameness grade } \\
\text { (Obel, 1948), increased digital pulses, abnormal } \\
\text { posture and inability or unwillingness to move } \\
\text { - Long-term outcome on horses that developed laminitis and } \\
\text { discharged from hospital included telephone conversations } \\
\text { with owners, trainers and referring veterinary surgeon }\end{array}$ \\
\hline $\begin{array}{l}\text { Main findings: } \\
\text { (relevant to PICO question): }\end{array}$ & $\begin{array}{l}\text { 27/130 horses (21\%) developed laminitis, } 103 / 130 \text { horses (79\%) did } \\
\text { not } \\
\text { - } 7 / 69 \text { (10\%) horses with CDH developed laminitis, } 3 / 7 \text { (43\%) } \\
\text { were euthanised prior to hospital discharge due to laminitis } \\
\text { - 20/61 (33\%) horses with no CDH developed laminitis, } 11 / 20 \\
(55 \%) \text { were euthanised prior to hospital discharge due to } \\
\text { laminitis } \\
\text { - Horses were less likely to develop laminitis if they received } \\
\text { CDH compared with horses that did not receive CDH (odds } \\
\text { ratio 0.14; p=0.003). } \\
\text { - Hospital site was significantly associated with development } \\
\text { of laminitis. Bias may have been introduced in the reporting } \\
\text { of Potomac Horse Fever (PHF) } \\
\text { 15/27 (55\%) of horses with laminitis tested positive } \\
\text { for PHF } \\
\text { 25/48 (52\%) of horses at University B colitis cases } \\
\text { were PHF positive, compared to } 25 / 82 \text { (30\%) of } \\
\text { University A colitis cases } \\
\text { only } 89 / 130 \text { ( } 68 \% \text { ) of horses in the study were } \\
\text { tested for PHF so the variable was not included in } \\
\text { the regression analysis } \\
\text { 114/130 (88\%) horses discharged from hospital } \\
16 / 130 \text { horses (12\%) were euthanised in hospital; of which } \\
14 / 16 \text { were euthanised due to laminitis. } 2 / 103 \text { horses } \\
\text { without laminitis were euthanised due to severity of the } \\
\text { gastrointestinal disease and poor response to therapy }\end{array}$ \\
\hline Limitations: & $\begin{array}{l}\text { - Only horses that developed laminitis were followed up after } \\
\text { hospital discharge } \\
\text { - Ponies, miniature and draught breeds were excluded from } \\
\text { the study }\end{array}$ \\
\hline
\end{tabular}




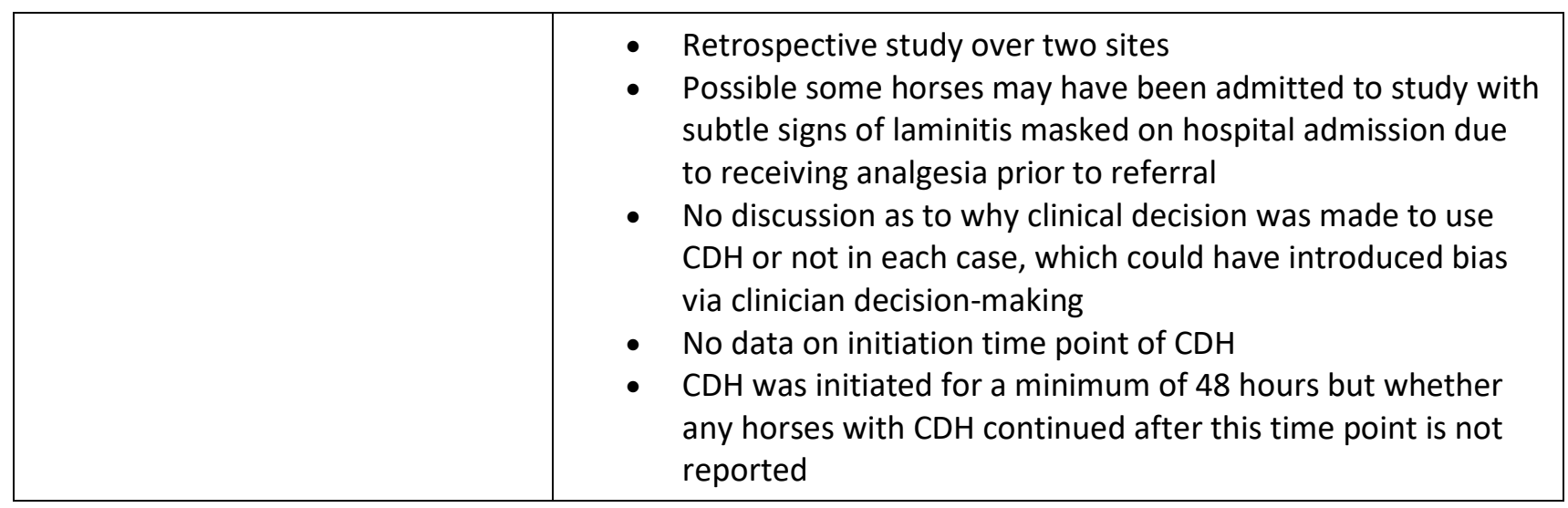

van Eps et al. (2014)

\begin{tabular}{|c|c|}
\hline Population: & $\begin{array}{l}\text { Clinically normal Standardbred geldings (aged } 3-11 \text { years). All horses } \\
\text { were reported to be sound, with no gross or radiographic } \\
\text { abnormalities of the feet. }\end{array}$ \\
\hline Sample size: & Eight horses \\
\hline Intervention details: & $\begin{array}{l}\text { - All horses housed and fed in stables for } 4 \text { weeks prior to the } \\
\text { experiment } \\
\text { - Laminitis induction via bolus of } 10 \mathrm{~g} / \mathrm{kg} \text { OF dissolved in water } \\
\text { and administered via nasogastric tube } \\
\text { - Horse confined to stocks and monitored for lameness every } \\
4 \text { hours beginning } 12 \text { hours after bolus of OF } \\
\text { - Two investigators were required to recognise and agree on } \\
\text { Obel Grade } 2 \text { lameness (Obel, 1948) to initiate CDH and } \\
\text { perineural anaesthesia } \\
\text { - CDH was initiated } 12 \text { hours post OF administration (OF } \\
\text { group) or } 12 \text { hours after confinement in stocks (control } \\
\text { group) } \\
\text { For each horse: } \\
\circ \quad \text { random allocation of one forelimb per horse for CDH } \\
\circ \quad \text { CDH forelimb placed in a rubber boot filled with } 50 \% \\
\text { water and } 50 \% \text { ice to the level of the proximal } \\
\text { metacarpus } \\
\text { - other forelimb left at ambient temperature } \\
\text { - } \begin{array}{l}\text { Euthanasia via pentobarbital sodium } 36 \text { hours after the } \\
\text { beginning of the experimental period }\end{array} \\
\text { of eight CDH forelimbs, plus eight control forelimbs and } 16 \\
\text { hindlimbs left at ambient temperature) } \\
\text { Concurrent treatments: } \\
\text { immediately on recognition of lameness, analgesia } \\
\text { was initiated via a single phenylbutazone injection (8 } \\
\text { mg/kg bwt IV) } \\
\text { bilateral forelimb continuous perineural analgesia } \\
\text { (palmar nerve block) via catheter placement with } 2 \\
\text { ml } 2 \% \text { mepivacaine hydrochloride hourly } \\
\text { intermittent perineural analgesia of hindlimbs if a } \\
\text { subjective increase in weight shifting was noted }\end{array}$ \\
\hline
\end{tabular}




\begin{tabular}{|c|c|}
\hline Study design: & $\begin{array}{l}\text { Randomised, controlled (within subject), blinded, experimental } \\
\text { study }\end{array}$ \\
\hline Outcome studied: & $\begin{array}{l}\text { - Pedometers taped to antebrachium and recorded every } \\
\text { hour, monitoring step count of individual limbs } \\
\text { - Forelimb hoof temperature monitored via thermistors } \\
\text { attached to the hoof surface } \\
\text { - Histological examination by two blinded observers was } \\
\text { based on basement membrane (BM) separation from the } \\
\text { lamellae in increasing severity: } \\
\circ \quad \text { Grade 0: normal } \\
\circ \quad \text { Grade 1: mild changes } \\
\circ \quad \text { Grade 2: moderate changes } \\
\circ \quad \text { Grade 3: severe and extensive changes } \\
\circ \quad \text { Grade 4: complete physical separation of lamellar } \\
\text { epidermis from dermis, with no association between } \\
\text { epidermal and dermal tissues on the section }\end{array}$ \\
\hline $\begin{array}{l}\text { Main findings: } \\
\text { (relevant to PICO question): }\end{array}$ & $\begin{array}{l}\text { - All eight horses developed Obel Grade } 2 \text { lameness within } \\
\text { 17-21 hours of OF administration } \\
\text { Pedometer data demonstrated increased frequency of limb } \\
\text { movement in the ambient temperature limbs compared to } \\
\text { the cooled limbs after the initiation of peripheral nerve } \\
\text { blocks and CDH } \\
\text { - After initiation of the perineural analgesia and CDH, the CDH } \\
\text { treated limb pedometer count frequency was significantly } \\
\text { decreased at 5-14, } 17 \text { and } 22 \text { hours compared with the } \\
\text { onset of lameness ( } 0 \text { hours) } \\
\text { - Median hoof wall surface temperature was } 7.1^{\circ} \mathrm{C} \text { for the } \\
\text { CDH feet and } 30.2^{\circ} \mathrm{C} \text { for the ambient feet } \\
\text { Histology: } \\
\text { - Median histological scores significantly greater in the } \\
\text { ambient limbs (proximal } 2.8 \text { [IQR } 2.5-4] \text {; middle } 3.5 \text { [IQR } 2- \\
4] \text {; distal } 2.5 \text { [IQR } 2-3.8] \text { ) compared to the } \mathrm{CDH} \text { limbs } \\
\text { (proximal } 0.5 \text { [IQR } 0.5-1.4] \text {; middle } 1 \text { [IQR } 0.6-1] \text {; distal } 0.75 \\
\text { [IQR } 0.5-1 \text { ] } \\
\text { CDH initiated at the onset of lameness reduced the severity } \\
\text { of lamellar injury } \\
\text { Complete physical separation of dermal and epidermal } \\
\text { lamellae in four ambient temperature feet which was not } \\
\text { observed in any of the CDH feet }\end{array}$ \\
\hline Limitations: & $\begin{array}{l}\text { - Analgesia via continuous peripheral nerve block is not } \\
\text { common practice in many clinical situations - this was done } \\
\text { as a humane consideration in this experimental study } \\
\text { - The study was only continued for } 36 \text { hours after the onset of } \\
\text { lameness so it is unclear whether the laminitis lesions in the } \\
\text { CDH feet may have progressed after discontinuation of the } \\
\text { cooling } \\
\text { - Small sample size } \\
\text { - Only Standardbred horses included }\end{array}$ \\
\hline
\end{tabular}




\begin{tabular}{|c|c|}
\hline Population: & $\begin{array}{l}\text { Clinically normal Standardbred horses ( } 10 \text { geldings and four mares; } \\
\text { aged } 4-11 \text { years). All horses were reported to be sound, with no } \\
\text { gross or radiographic abnormalities of the feet. }\end{array}$ \\
\hline Sample size: & 14 horses \\
\hline Intervention details: & $\begin{array}{l}\text { - Horse confined to stocks } \\
\text { - Laminitis induction via bolus of } 10 \mathrm{~g} / \mathrm{kg} \text { OF dissolved in water } \\
\text { and administered via nasogastric tube } \\
\text { - For each horse: } \\
\quad \text { CDH forelimb placed in a rubber boot filled with } 50 \% \\
\text { water and } 50 \% \text { ice to a level just below the carpus } \\
\quad \text { other forelimb left at ambient temperature } \\
\text { - Experiment } 1 \text { (eight horses): Euthanised } 24 \text { hours after OF } \\
\text { bolus (with no lameness) and tissues collected } \\
\text { - Experiment } 2 \text { (six horses): Euthanised immediately upon } \\
\text { recognition of Obel Grade } 1 \text { lameness between } 20-28 \text { hours } \\
\text { post OF bolus } \\
\text { One horse from Experiment } 1 \text { became lame at } 20 \text { hours and } \\
\text { was euthanised immediately so included in Experiment } 2 \\
\text { meaning Experiments } 1 \text { and } 2 \text { both include seven horses } \\
\text { Euthanasia immediately post anaesthetic induction with } \\
\text { immediate harvesting of dorsal lamellae snap frozen in liquid } \\
\text { nitrogen } \\
\text { Control lamellar tissue from a previous study used for } \\
\text { comparison }\end{array}$ \\
\hline Study design: & Controlled experimental study \\
\hline Outcome studied: & $\begin{array}{l}\text { - Onset of Obel Grade } 1 \text { lameness (Obel, 1948) } \\
\text { - Forelimb hoof temperature monitored via thermistors } \\
\text { attached to the hoof surface } \\
\text { - Pedometer readings from Experiment } 2 \text { to monitor weight } \\
\text { shifting }\end{array}$ \\
\hline $\begin{array}{l}\text { Main findings: } \\
\text { (relevant to PICO question): }\end{array}$ & $\begin{array}{l}\text { - Pedometer counts significantly higher in ambient limbs } \\
\text { compared to CDH limbs at } 18 \text { and } 20 \text { hours, compared to } 2 \\
\text { hours time point }(p<0.05) \\
\text { - In all cases, the pedometer data showed an increase in } \\
\text { count frequency in ambient temperature limbs } 2-4 \text { hours } \\
\text { prior to visual recognition of weight shifting behaviour } \\
\text { - Hoof wall surface temperature (mean } \pm \text { standard error): } \\
\circ \mathrm{CDH} \text { limbs } 4.2^{\circ} \pm 52^{\circ} \mathrm{C} \\
\circ \text { ambient limbs } 23.1^{\circ} \pm 1.4^{\circ} \mathrm{C}\end{array}$ \\
\hline Limitations: & $\begin{array}{l}\text { - Selection bias may have been introduced as study does not } \\
\text { mention whether CDH limb was randomly selected or how } \\
\text { selection of horses into different experimental groups was } \\
\text { achieved } \\
\text { - Control tissue for histology was not from this study although } \\
\text { had been harvested in an identical fashion } \\
\text { - Only Standardbred horses were included } \\
\text { - Small sample size }\end{array}$ \\
\hline
\end{tabular}




\begin{tabular}{|c|c|}
\hline Population: & $\begin{array}{l}\text { Clinically normal Standardbred horses ( } 14 \text { geldings, four mares). All } \\
\text { horses were reported to be sound, with no gross abnormalities of } \\
\text { the feet. }\end{array}$ \\
\hline Sample size: & 18 horses \\
\hline Intervention details: & 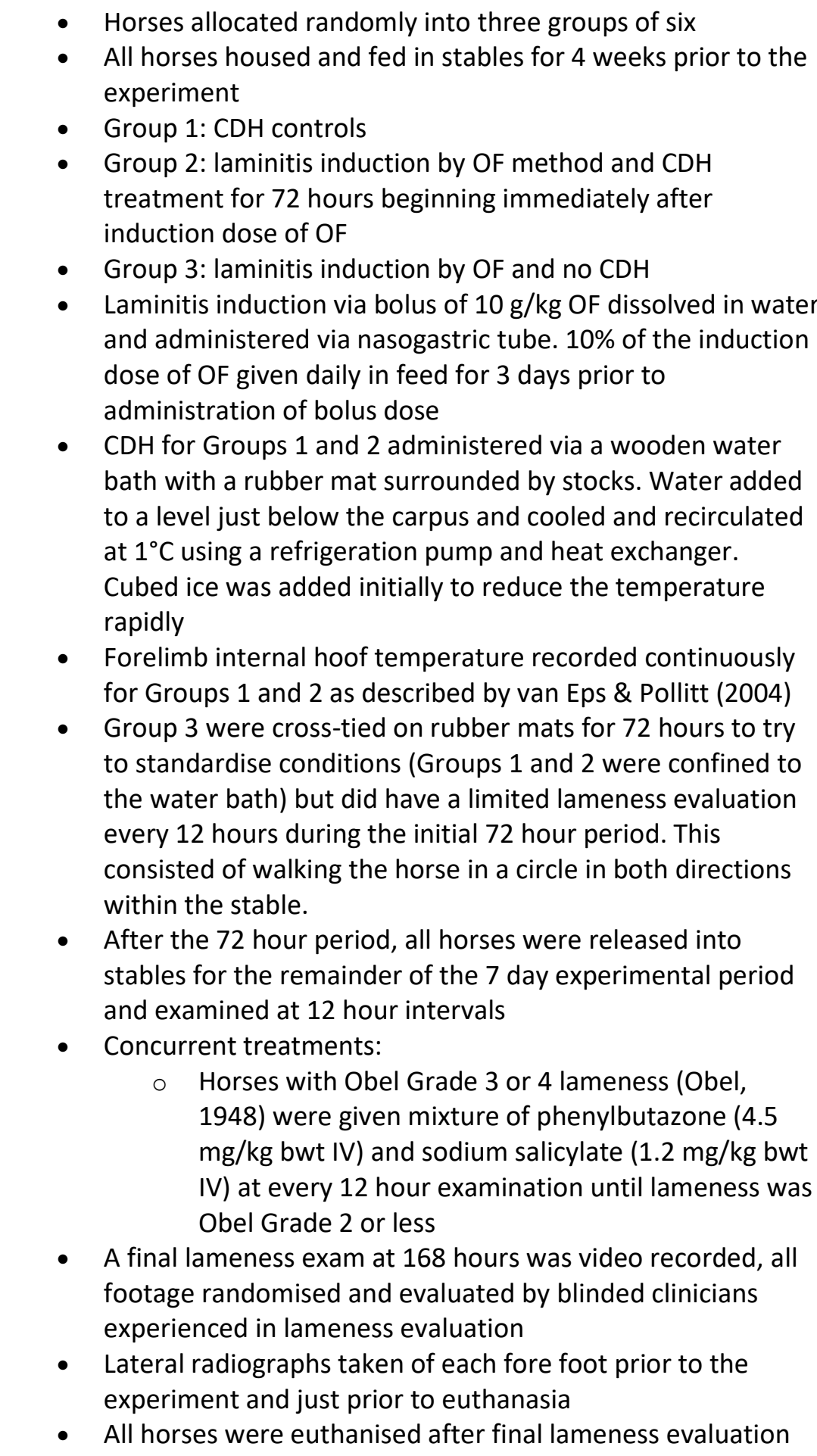 \\
\hline Study design: & Controlled experimental study \\
\hline Outcome studied: & $\begin{array}{l}\text { - Continuous recording of forelimb internal hoof temperature } \\
\text { in Groups } 1 \text { and } 2\end{array}$ \\
\hline
\end{tabular}




\begin{tabular}{|c|c|}
\hline & $\begin{array}{l}\text { - Lateral radiographs of each foot to assess changes during } \\
\text { study and between groups } \\
\text { - Histology of dorsal hoof lamellae to measure lamellar length }\end{array}$ \\
\hline $\begin{array}{l}\text { Main findings: } \\
\text { (relevant to PICO question): }\end{array}$ & 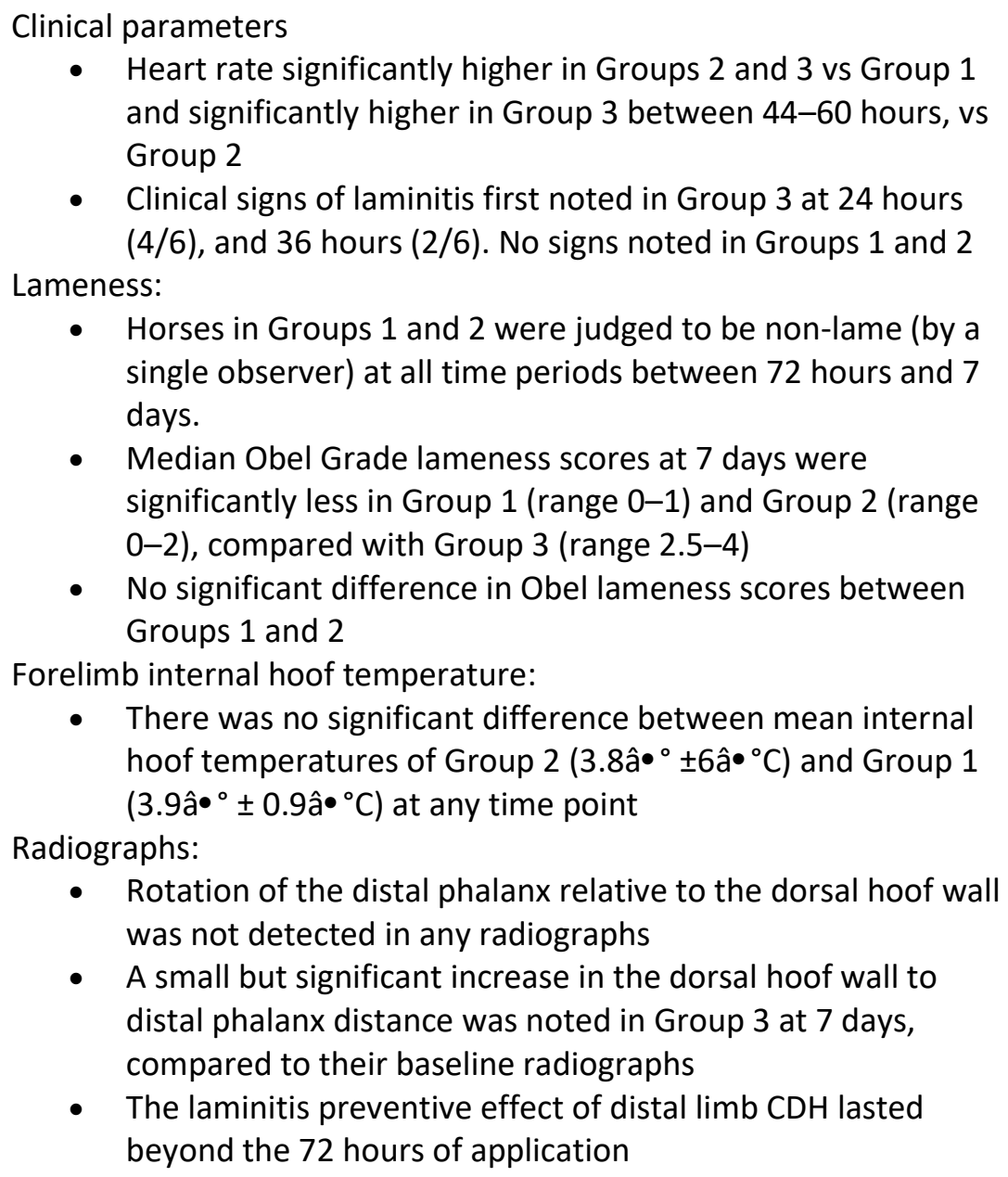 \\
\hline Limitations: & $\begin{array}{l}\text { The authors of the study noted the design of wooden water } \\
\text { bath was cumbersome, difficult to maintain and required } \\
\text { constant supervision. This would not be a practical method } \\
\text { of CDH in clinical practice } \\
\text { - There was no internal hoof temperature monitoring for } \\
\text { Group } 3 \text {. Depending on ambient temperature at the time of } \\
\text { the study this could have meant results for Group } 3 \text { would } \\
\text { have been significantly different to Groups } 1 \text { and } 2 \text {. } \\
\text { - Bias may have been introduced in Group } 3 \text { by allowing some } \\
\text { movement where the horses in the water bath had none for } \\
\text { - Only hours } \\
\text { - Small sample size }\end{array}$ \\
\hline
\end{tabular}




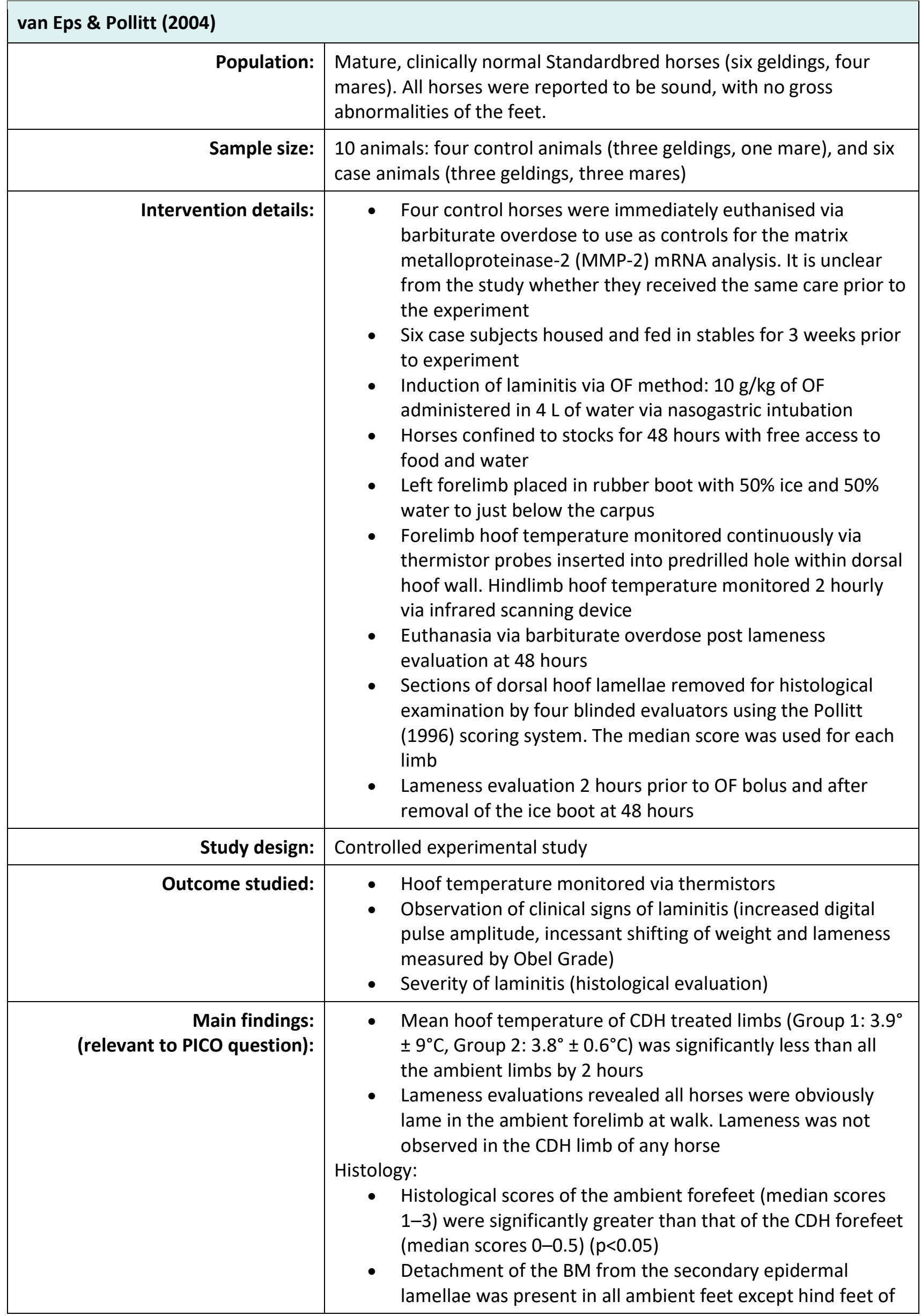




\begin{tabular}{|c|c|}
\hline & $\begin{array}{l}\text { one subject } \\
\text { - Detachment of the BM was not seen in any of the } \mathrm{CDH} \text { feet }\end{array}$ \\
\hline Limitations: & $\begin{array}{l}\text { - All horses had the left forelimb CDH treated } \\
\text { - Lameness evaluation was not blinded } \\
\text { - Different devices were used to measure temperature in } \\
\text { - } \quad \text { Only Standimbs and hindlimbs } \\
\text { - Small sample size }\end{array}$ \\
\hline
\end{tabular}

\section{Appraisal, application and reflection}

Laminitis is a common problem affecting equids seen in practice (Wylie et al., 2011). It is often debilitating and can cause severe morbidity and mortality. Acute laminitis may occur as a complication of various primary systemic diseases (van Eps, 2010), excessive unilateral weight bearing (Wylie et al., 2015) or, most commonly as a consequence of hyperinsulinaemia (de Laat et al., 2010; and Patterson-Kane et al., 2018).

The seven papers summarised all contribute some evidence towards the question of whether CDH can help improve clinical outcome in cases of acute laminitis. All the experimental studies deal with continuous digital hypothermia, and horses receiving intermittent digital hypothermia in the case series by Kullmann et al. (2014) were excluded.

The study by van Eps \& Pollitt (2009) reported that CDH, when performed for 72 hours on six horses that had not undergone laminitis induction, did not produce any significant lameness or other ill-effects. The horses appeared to tolerate $\mathrm{CDH}$ well, although distal limb oedema was reported in all $18 \mathrm{CDH}$ treated horses, which resolved by 7 days following cessation of treatment (van Eps \& Pollitt, 2009). A hypothesis provided by the study's authors was that this was a consequence of the cryotherapy in conjunction with restricted ambulation for 72 hours. All other included studies reported using CDH for a minimum of 36 hours with no significant sideeffects, demonstrating that $\mathrm{CDH}$ is safe to use in horses.

Most of the experimental studies included appear to build on the work of van Eps \& Pollitt (2004), refining the experimental model to often include randomisation and blinding of lameness exams which should serve to increase the quality of evidence. These experimental studies have limitations with regards to generalisability towards general clinical practice as the $\mathrm{CDH}$ was initiated prior to or immediately after induction of laminitis both by the oligofructose (OF) method (van Eps \& Pollitt, 2004; van Eps \& Pollitt 2009; and van Eps et al., 2012) and the euglycaemic hyperinsulinaemic clamp (EHC) method (Stokes et al., 2019). However, results obtained using the OF method support the prophylactic use of $\mathrm{CDH}$ in clinical cases considered to be at risk of sepsisassociated laminitis (van Eps \& Pollitt, 2004; van Eps \& Pollitt 2009; and van Eps et al., 2012). In the study by Dern et al. (2018), CHD was initiated 12 hours after induction of laminitis, however this was still before all but one of the horses showed any signs of lameness. In the van Eps et al. (2014) study CDH was initiated in one forelimb only after the onset of lameness was agreed upon by two investigators, providing evaluation of the protective effects of $\mathrm{CDH}$ at a more clinically relevant time point, and the most robust evidence relating to clinical practice of all the experimental studies. Although still limited by the small sample size, this study provides evidence of a therapeutic effect of $\mathrm{CDH}$ when applied after the onset of clinically apparent laminitis.

Stokes et al. (2019) was the only experimental study of insulin-induced laminitis. The main limitation to clinical application in this study is that $\mathrm{CDH}$ was initiated at the time of laminitis induction, before recognition of clinical laminitis. However, the results of the study indicate that overall the protective effects of CDH were similar to those noted in the OF studies, with a reduction in the severity of laminitis, both clinically and histologically (Stokes et al. 2019). Further work would be needed to evaluate whether these protective effects extend beyond the CDH period as shown in the OF method by van Eps \& Pollitt (2009). 
As a retrospective analysis of clinical records, Kullmann et al. (2014) falls much lower on the hierarchy of evidence but was included here as it provides evidence of $\mathrm{CDH}$ being used in a clinically relevant scenario. In this case series, $\mathrm{CDH}$ was performed by submerging the limbs in ice just proximal to the metacarpophalangeal joint, as opposed to the level of the proximal metacarpus which was used in all other studies. There were many limitations to this study which must be borne in mind, particularly surrounding the recording and standardisation of why CDH treatment was initiated, how the cases were selected for CDH treatment, the lack of information regarding when $\mathrm{CDH}$ treatment was commenced, and whether $\mathrm{CDH}$ continued in any cases beyond the minimum 48 hours specified. The criteria stated that horses admitted to the hospital with acute or chronic laminitis or diagnosed with laminitis at the time of admission were excluded, so an assumption is made that CDH was started after they had arrived at hospital - similar to the timing used in the experimental study by van Eps et al. (2014). The authors note however that lameness at time of admission may have been masked in some cases by the administration of analgesics by the referring vet (Kullmann et al. 2014).

The histopathology results from all the studies must be used to try to extrapolate clinical outcome given that all of the horses in the experimental studies were euthanised before clinical outcome could be assessed. All studies where histological examination was undertaken (Stokes et al., 2019; Dern et al., 2018; van Eps et al., 2014; van Eps \& Pollitt, 2009; and van Eps \& Pollitt, 2004) reported significant reduction in histological scores for laminitic feet treated with CDH compared to untreated laminitic feet. As histological changes due to laminitis are assumed to be non-reversible and the $\mathrm{CDH}$ reduced histological lesion progression, the significant difference observed due to the $\mathrm{CDH}$ may subsequently improve clinical outcome. Clinical significance of the different histology gradings is still unknown and a major limitation to these studies is the severity of laminitis caused by the induction models. In many natural cases, the onset of laminitis is insidious and may not be spotted until well after the time period where $\mathrm{CDH}$ was initiated in these studies. All of the horses studied also had no history of laminitis and it would be interesting to compare effects of CDH on horses with pre-existing chronic laminitis.

The study by van Eps \& Pollitt (2009) provides the best evidence that the protective effects of CDH in acute laminitis continue after the CDH is discontinued. Horses were subjected to 72 hours of CDH immediately following laminitis induction before being euthanised 7 days after induction. Results of blinded Obel lameness grading just prior to euthanasia showed no significant difference in control horses in Group 1 (no laminitis induction but $\mathrm{CDH}$ performed) and horses in Group 2 (laminitis induction and CDH). However, Obel lameness scores in Group 3 (laminitis induction but no CDH) were significantly higher than in either Group 1 or 2. Histopathology revealed significant lamellar changes in Group 3, mild changes in Group 2 and no lamellar changes in Group 1 (van Eps \& Pollitt, 2009).

$\mathrm{CDH}$ resulted in a decrease in clinical signs of laminitis (decreased pedometer count (weight shifting)) in the cooled forelimb compared to the uncooled forelimb and compared to the pedometer count prior to initiation of CDH (van Eps et al., 2014). Euthanasia was performed after 36 hours of CDH and histological evaluation identified complete physical separation of dermal lamellae from epidermal lamellae in 4/8 uncooled feet, compared to 0/8 cooled feet (van Eps et al., 2014). At the proximal, middle and distal dorsal lamellar sections the median histological scores were significantly decreased in the $\mathrm{CDH}$ feet, compared to the uncooled feet (van Eps et al., 2014). The van Eps et al. (2012) study also reported an increase in pedometer count frequency in ambient temperature limbs 2-4 hours prior to a subjective visual recognition of weight shifting behaviour. Given that one limb was encased in a cumbersome ice boot, the subjective data may be subject to significant bias but the objective pedometer data may prove useful for further research into clinically relevant time periods to initiate $\mathrm{CDH}$. Reduced frequency of weight shifting was also reported in CDH treated limbs compared to ambient temperature limbs in the two other experimental studies where this was measured objectively using pedometers (Dern et al., 2018; Stokes et al., 2019). Additionally, reduced severity of lameness, as assessed by Obel Lameness Grades (van Eps \& Pollitt, 2009), and a reduced prevalence of lameness (van Eps \& Pollitt, 2004) were reported for CDH treated limbs compared to ambient temperature limbs. 
Given the PICO question related to $\mathrm{CDH}$ and supportive treatment compared to supportive treatment alone, it should be noted that there are other forms of supportive treatment in the management of laminitis than NSAIDs. Commonly foot supports or corrective foot trimming, deep bedding, dietary management, and other pharmaceuticals such as paracetamol or acepromazine are often employed in the treatment of laminitis. Due to the experimental nature of six of the studies, including these variables within the studies would have been difficult to achieve but this should be borne in mind when thinking about the applicability to general clinical practice.

Further research is required to determine whether the conclusions from the experimental studies included in this Knowledge Summary are applicable to all equidae and underlying causes of laminitis. It is reasonable to assume that these findings would translate to other large size breeds but future work needs to be done to evaluate the effectiveness of $\mathrm{CDH}$ in clinical situations, in equids other than Standardbred horses such as ponies or donkeys, and on the effectiveness in animals with a previous history of laminitis, or a history of equine metabolic syndrome and/or pituitary pars intermedia dysfunction. Prospective cohort studies of clinical cases utilising strict inclusion criteria could help evaluate application of $\mathrm{CDH}$ for treatment of acute laminitis in clinical practice.

In conclusion, there is moderate evidence demonstrating that $\mathrm{CDH}$ does reduce the severity and/or frequency of clinical signs of pain, such as weight shifting and lameness in experimentally induced laminitis in Standardbred horses. Histological examination of the lamellae in cases of experimentally induced laminitis demonstrates that $\mathrm{CDH}$ reduces epithelial inflammatory events and protects against lamellar separation, especially if initiated before clinical signs are apparent. There is weak evidence to show that CDH provides protective effects in true clinical situations and a lack of evidence to show it improves clinical outcome compared to supportive treatment alone.

\section{Methodology Section}

\begin{tabular}{|c|c|}
\hline \multicolumn{2}{|l|}{ Search Strategy } \\
\hline $\begin{array}{r}\text { Databases searched and dates } \\
\text { covered: }\end{array}$ & $\begin{array}{l}\text { PubMed accessed via the NCBI website (1910-2019) } \\
\text { CAB Abstracts (1977-2019) }\end{array}$ \\
\hline Search terms: & $\begin{array}{l}\text { Search terms used in both databases: } \\
\text { Laminitis AND (hypothermia OR cold OR cryotherapy) }\end{array}$ \\
\hline Dates searches performed: & 26 Aug 2019 \\
\hline
\end{tabular}

\begin{tabular}{|l|l|}
\hline Exclusion / Inclusion Criteria \\
$\qquad$\begin{tabular}{|l|l|} 
Exclusion: & Review, conference proceedings, book chapter, non-peer \\
& reviewed publication \\
- & Not in the English language \\
- & Could not be sourced \\
- & Additionally studies where evaluation of the effect of distal \\
& limb cryotherapy on clinical and histological signs of laminitis \\
& was not the primary focus were excluded
\end{tabular} \\
\hline Inclusion: & $\begin{array}{l}\text { Studies relating to the use of cryotherapy to treat acute laminitis in } \\
\text { equids, regardless of cause of laminitis, where clinical and/or } \\
\text { histological signs were the primary outcome measure(s) }\end{array}$ \\
\hline
\end{tabular}




\begin{tabular}{|c|c|c|c|c|c|c|}
\hline \multicolumn{7}{|c|}{ Search Outcome } \\
\hline Database & $\begin{array}{c}\text { Number } \\
\text { of } \\
\text { results }\end{array}$ & $\begin{array}{l}\text { Excluded - } \\
\text { did not } \\
\text { address } \\
\text { the PICO } \\
\text { question }\end{array}$ & $\begin{array}{l}\text { Excluded - } \\
\text { review / book } \\
\text { chapter / non- } \\
\text { peer reviewed } \\
\text { publication }\end{array}$ & $\begin{array}{l}\text { Excluded - not } \\
\text { in English } \\
\text { language }\end{array}$ & $\begin{array}{l}\text { Excluded - } \\
\text { could not be } \\
\text { sourced }\end{array}$ & $\begin{array}{c}\text { Total } \\
\text { relevant } \\
\text { papers }\end{array}$ \\
\hline PubMed & 31 & 19 & 5 & 0 & 0 & 7 \\
\hline $\begin{array}{l}\text { CAB } \\
\text { Abstracts }\end{array}$ & 68 & 23 & 28 & 8 & 2 & 7 \\
\hline \multicolumn{6}{|c|}{ Total relevant papers when duplicates removed } & 7 \\
\hline
\end{tabular}

\section{CONFLICT OF INTEREST}

The authors declare no conflict of interest.

\section{REFERENCES}

1. de Laat, M.A., McGowan, C.M., Sillence, M.N. and Pollitt, C.C. (2010). Equine laminitis: Induced by 48 hr hyperinsulinaemia in Standardbred horses. Equine Veterinary Journal. 42(2), 129-135.

DOI: http://dx.doi.org/10.2746/042516409X475779

2. Dern, K., van Eps, A., Wittum, T., Watts, M., Pollitt, C. and Belknap, J. (2018). Effect of continuous digital hypothermia on lamellar inflammatory signaling when applied at a clinically-relevant time point in the oligofructose laminitis model. Journal of Veterinary Internal Medicine. 32(1), 450-458.

DOI: https://dx.doi.org/10.1111/jvim.15027

3. Kullmann, A., Holcombe, S.J., Hurcome, S.D., Roessner, H.A., Hauptman, J.G., Geor, R.J. and Belknap, J. (2014). Prophylactic digital cryotherapy is associated with decreased incidence of laminitis in horses diagnosed with colitis. Equine Veterinary Journal. 46(5), 554-559.

DOI: https://doi.org/10.1111/evj.12156

4. Obel, N. (1948). Studies of the Histopathology of Acute Laminitis. Almgvist and Wilcsells Bottrykeri Ab Uppsala (Thesis).

5. Patterson-Kane, J.C., Karikoski, N.P. and McGowan, C.M. (2018). Paradigm shifts in understanding equine laminitis. The Veterinary Journal. 231, 33-40. DOI: http://dx.doi.org/10.1016/j.tvjl.2017.11.011

6. Pollitt, C.C. (1996). Basement membrane pathology: A feature of acute equine laminitis. Equine Veterinary Journal. 28(1), 38-46. DOI: https://dx.doi.org/10.1111/j.2042-3306.1996.tb01588.x

7. Stokes, S.M., Belknap, J.K., Engiles, J.B., Stefanovski, D., Bertin, F.R., Medina-Torres, C.E., Horn, R. and van Eps, A.W. (2019). Continuous digital hypothermia prevents lamellar failure in the euglycaemic hyperinsulinaemic clamp model of equine laminitis. Equine Veterinary Journal. 51(5), 658-664. DOI: https://doi.org/10.1111/evj.13072

8. van Eps, A.W. and Pollitt, C.C. (2004). Equine laminitis: cryotherapy reduces the severity of the acute lesion. Equine Veterinary Journal. 36(3), 255-260. DOI: https://doi.org/10.2746/0425164044877107 
9. van Eps, A.W. and Pollitt, C.C. (2009). Equine laminitis model: Cryotherapy reduces the severity of lesions evaluated seven days after induction with oligofructose. Equine Veterinary Journal. 41(8), 741746. DOI: https://doi.org/10.2746/042516409X434116

10. van Eps AW. (2010). Therapeutic hypothermia (cryotherapy) to prevent and treat acute laminitis. Veterinary Clinics of North American Equine Practice. 26(1), 125-33. DOI: https://doi.org/10.1016/j.cveq.2010.01.002

11. van Eps, A.W., Leise, B.S., Watts, M., Pollitt, C.C. and Belknap, J.K. (2012). Digital hypothermia inhibits early lamellar inflammatory signalling in the oligofructose laminitis model. Equine Veterinary Journal. 44(1), 120-124. DOI: https://doi.org/10.1111/i.2042-3306.2011.00416.x

12. van Eps, A.W., Pollitt, C.C., Underwood, C., Medina-Torres, C.E., Goodwin, W.A. and Belknap, J.K. (2014). Continuous digital hypothermia initiated after the onset of lameness prevents lamellar failure in the oligofructose laminitis model. Equine Veterinary Journal. 46(5), 625-630. DOI: https://doi.org/10.1111/evj.12180

13. Wylie, C.E., Collins, S.N., Verheyen, K.L., and Newton, J.R. (2011). Frequency of equine laminitis: a systematic review with quality appraisal of published evidence. The Veterinary Journal. 189(3), 248256. DOI: https://doi.org/10.1016/j.tvjl.2011.04.014

14. Wylie, C.E., Newton, J.R., Bathe, A.P., and Payne, R.J. (2015). Prevalence of supporting limb laminitis in a UK equine practice and referral hospital setting between 2005 and 2013: implications for future epidemiological studies. Veterinary Record. 176(3), 72. DOI: https://doi.org/10.1136/vr.102426 


\section{EVIIDEFeE

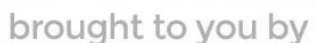 \\ RCVS KNOWLEDGE}

\section{Intellectual Property Rights}

Authors of Knowledge Summaries submitted to RCVS Knowledge for publication will retain copyright in their work, and will be required to grant RCVS Knowledge a non-exclusive license of the rights of copyright in the materials including but not limited to the right to publish, re-

publish, transmit, sell, distribute and otherwise use the materials in all languages and all media throughout the world, and to license or permit others to do so.

\section{Disclaimer}

Knowledge Summaries are a peer-reviewed article type which aims to answer a clinical question based on the best available current evidence. It does not override the responsibility

of the practitioner. Informed decisions should be made by considering such factors as individual clinical expertise and judgement along with patient's circumstances and owners' values. Knowledge Summaries are a resource to help inform and any opinions expressed within the Knowledge Summaries are the author's own and do not necessarily reflect the view of the RCVS Knowledge. Authors are responsible for the accuracy of the content. While the

Editor and Publisher believe that all content herein are in accord with current recommendations and practice at the time of publication, they accept no legal responsibility

for any errors or omissions, and make no warranty, express or implied, with respect to material contained within.

For further information please refer to our Terms of Use.

RCVS Knowledge is the independent charity associated with the Royal College of Veterinary Surgeons (RCVS). Our ambition is to become a global intermediary for evidence based veterinary knowledge by providing access to information

that is of immediate value to practicing veterinary professionals and directly contributes to evidence based clinical decision-making.

https://www.veterinaryevidence.org/

RCVS Knowledge is a registered Charity No. 230886.

Registered as a Company limited by guarantee in England and Wales No. 598443.

Registered Office: Belgravia House, 62-64 Horseferry Road, London SW1P 2AF

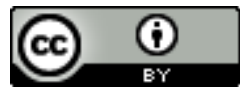

This work is licensed under a Creative Commons Attribution 4.0 International License 